\title{
Pengaruh Strategi Pemasaran Asuransi Mikro Terhadap Kesejahteraan UMKM di Indonesia
}

\author{
Muhammad Andre Alkahfi, Nuri Aslami \\ Universitas Islam Negeri Sumatera Utara \\ muhammad.andre.alkahfi@gmail.com, nuriaslami@uinsu.ac.id
}

\begin{abstract}
The purpose of this research is to explain a phenomena that happened in the Indonesian microinsurance business. Using the case study technique, we observed that microinsurance is still difficult to develop based on the overall population of Indonesians. If the main idea of micro insurance is applied, micro insurance products are still widely available in big cities but have yet to reach low-income individuals or UMKM. A breakthrough is necessary to produce microinsurance. This microinsurance business must be developed through a network of local communities, which are usually located in the lower middle class, or UMKM. Aside from that, marketers must have a set of tools at their disposal, such as a suitable ICT-based market (community) database. As a result, any microinsurance business formed must be targeted to the demands of the Indonesian government, such as microinsurance for agricultural, livestock, and fisherman, particularly in rural regions. Meanwhile, the most enticing micro insurance enterprises for metropolitan regions are personal accidents, property, and motor and vehicles.
\end{abstract}

Keywords: Micro, UMKM, Insurance, Marketing.

\begin{abstract}
Abstrak
Artikel ini berfokus untuk menjelaskan fenomena yang terjadi di industri asuransi mikro Indonesia. Dengan menggunakan metode studi kasus, kami menemukan bahwa berdasarkan jumlah penduduk Indonesia, asuransi mikro masih belum dapat berkembang. Jika mengacu pada konsep dasar asuransi mikro, produk asuransi miikro masih tersebar di kota-kota besar dan belum menjangkau daerah berpenghasilan rendah atau UMKM.. Untuk mengembangkan asuransi mikro, diperlukan terobosan. Usaha asuransii mikro ini perlu dikembangkan melalui jaringan komunitas kecil yang sebagian besar terdapat pada kalangan menengah ke bawah atau UMKM. Namun selain itu, pemasar harus dilengkapi dengan seperangkat alat, seperti database pasar (komunitas) berbasis TIK yang sesuai. Akibatnya, Semua kegiatan asuransi mikro yang dikembangkan harus memenuhi kebutuhan pemerintah Indonesia, seperti asuransi mikro untuk pertanian, peternakan dan perikanan, terutama di pedesaan. Di daerah perkotaan, perusahaan asuransi kecil yang paling populer adalah asuransi kecelakaan diri dan properti, sepeda motor dan kendaraan.
\end{abstract}

Katakunci: Mikro, UMKM, Asuransi, Pemasaran. 


\section{VISA: Journal of Visions and Ideas}

Vol 1 No 3 (2021) 261-273 E-ISSN 2809-2058 P-ISSN 2809-2643 DOI: 47467/visa.v1i3.795 


\section{Vol 1 No 3 (2021) 261-273 E-ISSN 2809-2058 P-ISSN 2809-2643 DOI: $47467 /$ visa.v1i3.795}

\section{PENDAHULUAN}

Istilah "asuransi mikro" pertama kali digunakan di Indonesia pada tahun 2013, saat Otoritas Jasa Keuangan (OJK) menyelenggarakan Grand Design Asuransi Mikro di Indonesia. Sejak didirikan lima tahun lalu, industri asuransi mikro di Indonesia telah membuahkan hasil yang sangat baik. Hal ini ditunjukkan dengan banyaknya perusahaan asuransi yang menyediakan asuransi mikro, jumlah produk yang dijual, dan jumlah masyarakat yang mendukungnya. Namun, menurut OJK (Otoritas Jasa Keuangan) pada Industri Keuangan Non Bank (IKNB) Syariah, potensi asuransi mikro di Indonesia lebih besar dari jumlah penduduk. Pada akhir Desember 2017, jumlah orang yang membutuhkan asuransi mikro telah meningkat menjadi 21.797.185 atau kurang dari 10\% dari seluruh penduduk Indonesia. Terakhir, Di penghujung tahun 2019, Otoritas Jasa Keuangan (OJK) mengumumkan bahwa penghargaan kecil tersebut telah diubah menjadi Rp 3,2 triliun dengan total 25,86 juta pelanggan. Namun, jumlah gugatan adalah 129,638 dengan nilai nominal 608 juta (Ahmad Al-Ghaffari) (25 November 2019). Selain itu, menurut statistik 0JK, 63 perusahaan mengembangkan produk asuransi mikro untuk tahun 2017, yang dapat dikategorikan menggunakan grafik di bawah ini:

Tabel 1

Distribusi Frekuensi Perusahaan Pengelola Asuransi Mikro di Indonesia

\begin{tabular}{ccc}
\hline No. & Interval kelas & Frekuensi kelas \\
\hline 1 & $3-873.938$ & 54 \\
2 & $873.939-1.747 .774$ & 4 \\
3 & $1.747 .775-2.621 .710$ & 1 \\
4 & $2.621 .711-3.495 .646$ & 2 \\
5 & $3.495 .647-4.367 .582$ & 0 \\
6 & $4.367 .583-5.243 .518$ & 2 \\
\hline \multicolumn{2}{l}{ Jumlah } & 63 \\
\hline
\end{tabular}

Berdasarkan kategori tersebut di atas, hanya ada dua perusahaan asuransi yang menyediakan asuransii mikro, dengan jumlah nasabah 4.367.583 - 5.243.518 nasabah. Jika dibandingkan dengan jumlah penduduk Indonesia, jumlah ini cukup besar. Menurut perkiraan tahun 2016, jumlah penduduk Indonesia kurang lebih 261,115,456 jiwa. Indikator ini menunjukkan bahwa untuk pertama kalinya, sekitar 8.347 persen masyarakat Indonesia tercakup dalam produk asuransi mikro.

Sebagaimana tertuang dalam Sustainable Development Goals (SDGs), struktur asuransi mikro masih lebih rendah dari yang diharapkan (Statistik Biro, 2015). Asuransi mikro terkait erat dengan enam (enam) program Tujuan Pembangunan Berkelanjutan, yaitu (1) pengentasan segala bentuk kemiiskinan dimanapun berada, (2) memerangi kelaparan, peningkatan ketahanan pangan dan gizi, serta pemajuan pertanian). Menjamin kesehatan hidup dan kesejahteraan umum penduduk, (4) dapat mencapaii kesetaraan gender dan partisipasi semua perempuan dan anak perempuan, (5) mencapai pertumbuhan ekonomi yang inklusif dan berkelanjutan serta pekerjaan layak yang berkelanjutan untuk kepentingan semua, dan (6) dapat segera untuk memerangi perubahan iklim dan tindakan. 
Oleh karena itu, terutama berdasarkan pada alasan permasalahan di atas, penelitian ini secara kualitatif mengkaji usaha mikro di Indonesia, terkait dengan menikmati perusahaan pengendali cakupan mikro yang saat ini telah maju dan mengeluarkan banyak barang dan jasa cakupan mikro. Kesadaran dari penelitian ini adalah untuk meneliti peningkatan usaha mikro di Indonesia.

\section{KAJIAN TEORI}

Ungkapan "asuransi mikro" muncul di media cetak pertama kali pada tahun 1999. Frasa ini masih berkembang dan diperdebatkan dalam berbagai konteks. Beberapa di antaranya dapat diliahat di bawah ini, antara lain (networkmicroinsurance, 2009), Asuransi mikro adalah jenis asuransi yang memberikan perlindungan finansial kepada Massyarakat berpendapatan rendah menghadapi risiko tertentu sebagai imbalan atas pembayaran rutin bulanan yang sebanding dengan risiko yang terlibat.(Preliminary Guidelines, 2003).

Sistem ini juga merupakan alat transfer risiko dengan tingkat premi rendah dan ambang kelulusan rendah yang dikembangkan bagi orang-orang berpendapatan rendah yang tidak tercakup oleh asuransi sosial tradisional (Micro Insurance Academy, India, 2007), dengan tujuan mengambil manfaat dari dukungan yang buruk terhadap riisiko (kecelakaan), sakit dan kematian dalam keluarga dan bencana alam dengan membayar premi asuransi sesuai kebutuhan, pendapatan dan tingkat risiko (Fasilitas Inovasi Asuransi Mikro ILO, 2008). Program ini juga menjadi pilihan bagi rumaah tangga berpenghasilan rendah untuk mengendalikan risikonya (Swiss Reiinsurance,2010).

Secara umum, asuransi mikro melindungi masyarakat berpenghasilan rendah dari risiko tertentu dengan imbalan pembayaran premi berkala yang sebanding dengan kemungkinan dan biaya risiko yang terlibat. Dengan pengecualian target pasar yang terdefinisi dengan baik: Individu dengan pendapatan kecil, definisi ini hampir sama dengan definisi yang dapat digunakan untuk asuransi standar. Kawasan Asia-Pasifik, yang merupakan rumah bagi sekitar $70 \%$ penduduk miskin dunia, merupakan pasar potensial yang sangat besar. Akibatnya, model asuransii mikro berbeda secara konseptual dari konsep asuransi tradisional secara keseluruhan. Karakterisasi Clarence Wong dan Amit Kalra(2010) menyajikan konsep asuransi mikro yang digunakan di banyak negara. 


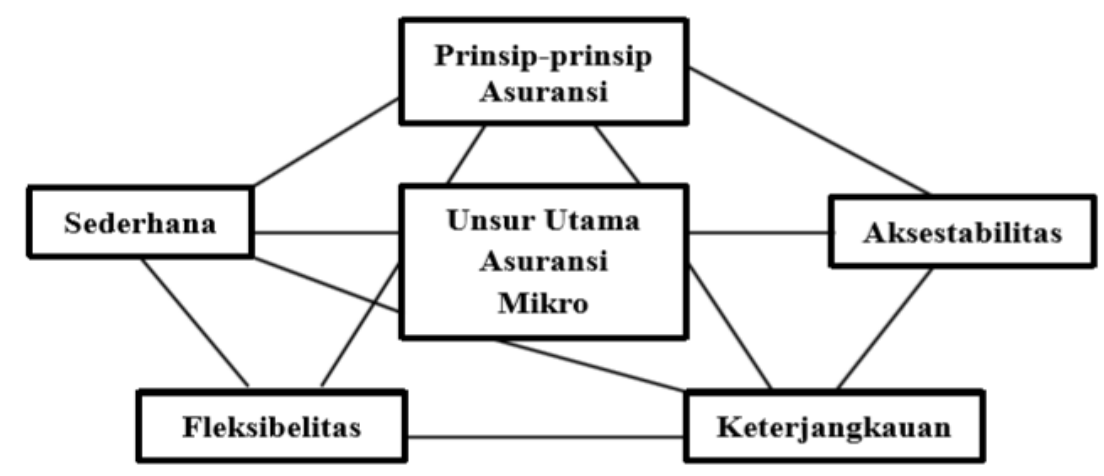

\section{Gambar 2 \\ Model Asuransi Mikro (Amit Kalra dan Clarence Wong, 2010)}

Mirko Bendig, Shoba Arun, dan Thankom Arun (2012) menemukan bahwa Penggunaan model tobit dan probit dengan menggunakan data survei rumah tangga di Sri Lanka menjadi faktor kunci dalam berpartisipasi dalam asuransi mikro untuk rumah tangga berpenghasilan rendah. Ada juga korelasi positif antara motivasi, keinginan dan jumlah anak atau kerabat. Namun, keuntungan atau kerugian dari sistem asuransi ini dapat diklasifikasikan antara anggotaa keluarga miskin di perkotaan dan pedesaan dan antara keluarga miskin dan membutuhkan. Manfaat atau hibah yang diterima masyarakat miiskin perkotaan lebih tinggi dibandingkan dengan masyarakat miskin pedesaan (McRanson, Tara Sinha, A.J. Mills, 2007).

Dalam beberapa tahun terakhir, sektor asuransi mikro telah berkembang pesat. Mayoritas industri sedang berjuang untuk memberikan polis asuransi ini. Produk yang diproduksi atau diproduksi memiliki risiko harga yang rendah. Masalah harga dengan pengaturan asuransi ini merupakan hambatan non-teknis dalam dirinya sendiri (Christian Biener, 2013). Kerangka peraturan diperlukan untuk memfasilitasi pertumbuhan sektor asuransi mikro. Lagi pula, aturan yang keras berpotensi mempengaruhi pertumbuhan sistem asuransi ini. Regulasi di sektor asuransi mikro dapat menjadi motivator sekaligus pencegah. Akibatnya, Insentif diperlukan dalam bentuk aturan arbitrase. Harus mencerminkan karakteristik pasaar mikro asuransi, termasuk perizinan, polis, reasuransi dan sistem distribusi. Anda perlu meningkatkan pasar melalui inisiatif literasi keuangan. Dan mereka harus didukung dengan pelatihan dalam pengumpulan dan pengelolaan data (Christian Banner, Joan T. Schmidt Martin Elling, 2014)

Menurut penelitian Bank Dunia tentang asuransi mikro (2013), premi asuransii mikro tidak boleh melebihi Rp 50.000 dengan premis risiko harga $\mathrm{Rp}$ 50.000 ,- dan minimal 10.000 polis terjual = Rp. 500.000.000. Jika dibandingkan dengan kompensasi bulanan khas kepala perusahaan asuransi, harga ini terlalu rendah. Jika asumsi ini diterapkan pada perusahaan asuransi tradisional, maka perkembangan asuransi mikro akan sangat sulit. Apalagi jika kekuatan pasar asuransi mikro bukanlah tujuan dari pasar asuransi tradisional. Individu dengan 


\section{VISA: Journal of Visions and Ideas}

\section{Vol 1 No 3 (2021) 261-273 E-ISSN 2809-2058 P-ISSN 2809-2643 DOI: $47467 /$ visa.v1i3.795}

pendapatan rendah dan pemahaman asuransi dasar yang sedikit adalah target pasar untuk asuransi mikro. Akibatnya, menjual asuransi mikro memerlukan teknik yang berbeda. Metode ini jelas berbeda dari strategi yang sebelumnya digunakan dalam pemasaran asuransi tradisional.

\section{METODE PENELITIAN}

Desain penelitian yang dikembangkan adalah desain kualitatif dengan sub metode studi kasus. Kajian ini mendalami industri asuransi mikro di Indonesia untuk mengumpulkan informasi. Partisipan dalam penelitian ini adalah para pelaku industri asuransi mikro. Untuk mengungkap suatu masalah tertentu, penelitian ini menggunakan pendekatan studi kasus, yaitu metode penelitian kualitatif. Selanjutnya, di penelitian ini, eksplorasi dilakukan dalam konteks yang terbatas untuk jangka waktu tertentu, dengan analisis yang mendalam dan pengumpulan data yang mendalam dari berbagai sumber. Berdasarkan topik yang disampaikan, rangkaian data menghasilkan deskripsi kasus.

\section{HASIL PENELITIAN DAN PEMBAHASAN}

Studi ini mengambil tempat di sebuah perusahaan asuransi yang menawarkan pertanggungan asuransi mikro. OJK - Menurut Industri Keuangan Non Bank (IKNB), pada tahun 2017 terdapat 63 pelaku usaha asuransi di indonesia yang memasarkan atau memproduksi produk asuransi mikro.

Pertumbuhan ekonomi yang positif di Indonesia tidak terlepas dari kesadaran akan asuransi, terutama di kalangan masyarakat berpenghasilan rendah. Data saat ini menunjukkan bahwa dampak pasar asuransi Indonesia masih kecil dibandingkan negara tetangga seperti Malaysia dan Singapura. Asuransi itu wajib untuk semua jenis kalangan. 


\section{VISA: Journal of Visions and Ideas}

\section{Vol 1 No 3 (2021) 261-273 E-ISSN 2809-2058 P-ISSN 2809-2643 DOI: 47467/visa.v1i3.795}

\section{Pemasaran Produk dan Jasa Asuransi Mikro di Indonesia}

Ada Beberapa perusahaan telah memproduksi produk asuransi mikro sejak 2013, ketika Grand design asuransi mikro Indonesia pertama kali meluncurkan program asuransi mikro, Namun demikian, PT Asuransi Jasaraharja Putra pertama kali memperkenalkan produk ini pada tahun 1994. Sejauh ini, 63 perusahaan operasional telah muncul dari ide besar asuransi mikro Indonesia. Sejak tahun 2017, Indonesia mulai menggunakan teknologi digital untuk mengiklankan barang jasa asuransi mikro.

PT. Jiwasraya Insurance, PT. Asuransi Allianz Life, serta MNC Life Assurance merupakan beberapa perusahaan asuransi yang saat ini mengelola produk berbasis digital. Pergeseran arah tujuan pasar asuransi, khususnya asuransi mikro, dari pengguna konvensional ke pengguna milenial merupakan fenomena menarik yang dihasilkan dari pemanfaatan teknologi ini. Keuntungan mengadopsi teknologii berbasis aplikasi juga sudah mulai terasa, karena biayanya yang lebih murah dan tidak membutuhkan banyak tenaga pemasar di lapangan. Menurut para ahli perusahaan, setidaknya ada tiga modell pengembangan pasar yang dapat memperluas industri asuransi mikro, yakni:

1. Harus menyediakan pemasar yang paham teknologi informasi,

2. Menggunakan sosial media, atau

3. Membuat aplikasi/software lebih dahulu.

Pendekatan pemasaran asuransi mikro, sebagaimana dikemukakan dalam pokok bahasan utama, menunjukkan bahwa teknologi berbasis aplikasi mobile berpotensi untuk diterapkan dalam pemasaran asuransi mikro. Untuk mempromosikan atau membuat kampanye (campaign) item layanan asuransi mikro, dapat digunakan platform media sosial seperti Whatsapp dan perangkat teknologi digital seperti ponsel (smartphonee).

Alhasil, untuk menyambut era digital, produk asuransi mikro harus sederhana, dengan penjelasan produknya sendiiri (tiidak ada penjaminan dan proses klaiim yang berkepanjangan). Hal ini juga dilakukan untuk mengurangi kekhawatiran hukum. Jika semua syarat dan ketentuan telah disajikan, pernyataan kesediaan disebutkan, dan pasal-pasal yang berkaitan dengan penolakan tersebut disahkan, maka risiko hukum dapat dihilangkan (Cahyo Auxentius Bintorro, 2018).

Penggunaan teknologi digital dalam pemasaran produk asuransi mikro diharapkan dapat membantu nasabah bukan menghambatnya. Misalnya, dalam kasus asuransi mikro, semua data peserta akan disimpan dengan benar di server. Kemungkinan kesalahan relatif minimal karena data disimpan dengan identitas yang unik. Satu identitas dapat digunakan untuk mengidentifikasi satu peserta (ID). Identitas unik ini adalah jenis keamanan peserta yang luar biasa. Selanjutnya, data peserta dan pembayaran premi yang diterima melalui saluran pembayaran dicatat secara "real-time" dalam sistem database. Jika peserta bermaksud untuk mengajukkan klaim, peserta/ahlii waris harus memberikan informasi yang benar 


\section{VISA: Journal of Visions and Ideas}

\section{Vol 1 No 3 (2021) 261-273 E-ISSN 2809-2058 P-ISSN 2809-2643}

DOI: 47467/visa.v1i3.795

saat memasukkan data awal (nama seperti pada KTP dan ahlli waris pada kartu keluarga) (Christ Kelley, 2018). 


\section{VISA: Journal of Visions and Ideas}

\section{Vol 1 No 3 (2021) 261-273 E-ISSN 2809-2058 P-ISSN 2809-2643 DOI: 47467/visa.v1i3.795}

\section{Strategi dan Sumber Daya Bisnis untuk Pemasar Asuransi}

Manajer Perusahaan saat ini dihadapkan pada lingkungan bisnis yang sangat dinamis yang ditandai dengan inovasi teknologi, pengaburan segmen, perubahan perilaku pelanggan, kurangnya bakat, dan tingkat pertumbuhan yang bervariasi. Kinerja sumber daya manusia harus membantu perusahaan mengatasi tantangan ini sebagai strategi mitra sejati. Untuk mencapai misi ini, para pemimpin SDM memerlukan gambaran yang jelas tentang keterampilan mereka saat ini, prioritas mereka untuk tiga hingga lima tahun ke depan, dan cara terbaik untuk menyesuaikan upaya peningkatan mereka. Jean-Michel Caye dan Rainer Strack, (2018), Pentingnya Industri Asuransi untuk Pengelolaan Talent and Employer Brands.

Kebijakan-kebijakan yang dikeluarkan oleh para penjual di tingkat lapangan merupakan landasan dari pergerakan komersial perusahaan asuransi. Dengan kata lain, operasi perusahaan asuransi berlangsung pada kantor operasional. Kegiatan usaha inii sangat bergantung pada atau sejalan dengan anggaran agar dapat dijalankan. Baiik anggaran penerimaan premi, anggaran klaim, anggaran SDM, anggaran biaya dan jumlah agen yang harus dimiliki semuanya harus dianggarkan. Semuanya harus diselesaikan sesuai dengan tujuan yang ditetapkan oleh pimpinan kantor operasional..

Akibatnya, kantor operasi memiliki sejumlah besar agen, supervisor, kepala cabang, dan karyawan administrasi yang tersebar di seluruh wilayah yang luas dengan tanggung jawab utama untuk penetrasi pasar. Pemilihan risiko, efisiensi biaya, dan kelebihan operasional merupakan langkah awal menuju penetrasi pasar. Sangat penting untuk memahami bahwa kurangnya surplus operasional menunjukkan bahwa perusahaan tidak menguntungkan.

Sedangkan operasi di kantor pusat berfungsi sebagai pusat komando dan kendali bagi personel di kantor operasional. Semua kontrol dan kegiiatan operasional yang terkendali harus dapat berkontribusi pada surplus operasional pusat. Kelebihan underwriting, surplus biaya, dan surplus investasi adalah bagian dari surplus. Jadi ketiga hal ini harus disediakan agar perusahaan mendapatkan keuntungan. Akibatnya, semua operasi kantor operasional harus diawasi secara memadai dari kantor pusat. Ada kantor operasional dan operasi kantor pusat di industri itu.

Profesional yang bekerja di bisnis asuransi harus memiliki pengetahuan untuk memasuki pasar. Pengetahuan ini memanifestasikan dirinya dalam bentuk penciptaan nilai melalui database pasar (membuat database pasar). Lagi pula, spesialis ini tidak akan dapat mengevaluasi pasarr mana yang paling potensial untuk digarap atau ditembus kecuali mereka memiliki akses ke database pasar. Seorang profesional asuransi harus memiliki pengetahuan di bidang komunikasi pasar agar dapat menembus pasar secara efektif. Profesional asuransi akan merasa sulit untuk mendapatkan penerimaan pasar kecuali mereka memiliki kapasitas dan memperoleh keterampilan komunikasi yang kuat. Tahap ini melanjutkan produksi dan administrasi kumpulan data pasar saat ini, yang kemudian dapat direplikasi. 


\section{VISA: Journal of Visions and Ideas \\ Vol 1 No 3 (2021) 261-273 E-ISSN 2809-2058 P-ISSN 2809-2643 DOI: 47467/visa.v1i3.795}

Selain itu, kapasitas untuk membuat jaringan (networking) harus dikembangkan. Selain kemampuan membangun jaringan, profesional asuransi juga harus mampu mengkomunikasikan keunggulan produk perusahaan. Keahliann ini sangat penting. Karena tanpa penguasaan ini, orang awam dan ahli dalam keunggulan produk tidak dapat membedakan antara produk yang ditawarkan dan pesaing.

Biasanya, rintangan yang dihadapi dalam organisasi perusahaan terkaiit, misalnya, ketika agen mengamati perusahaan lain memberikan metode kerja yang lebih longgar, rasio pembayaran yang lebih besar. Mereka hampir pasti akan memilih bekerja untuk orang lain. Agen terikat kontrak, oleh karena itu jika dia tidak cocok dengan majikannya, kemungkinan dia meninggalkan organisasi tinggi. Akibatnya, mengelola ahli seperti cara sangat jarang. Bagaimana mereka tidak dirugikan, untuk tetap bertahan sehingga profesionalisme dan produksi mereka dapat meningkatkan pendapatan mereka? Bahkan ketika ada penawaran yang lebih baik, pendapatannya terus meningkat asalkan bisa dijamin. Selanjutnyaa, ikatan emosional antara agen dan pemimpin dipelihara dengan baik (sehat), sehingga mereka dapat bertahan.

Untuk menjadi seorang profesional asuransi, Anda harus punya market match atau diterima oleh pasar. Nama lain untuk jenis segitiga ini adaalah segitiga tetap. Ini mencakup: (1) profesional yang dapat diakui oleh pasar; dan (2) para profesional yang memiliki kendali penuh atas barang-barang mereka. (3) Selanjutnya barang yang ditawarkan oleh profesional tersebut sesuai dengan permintaan pasar..

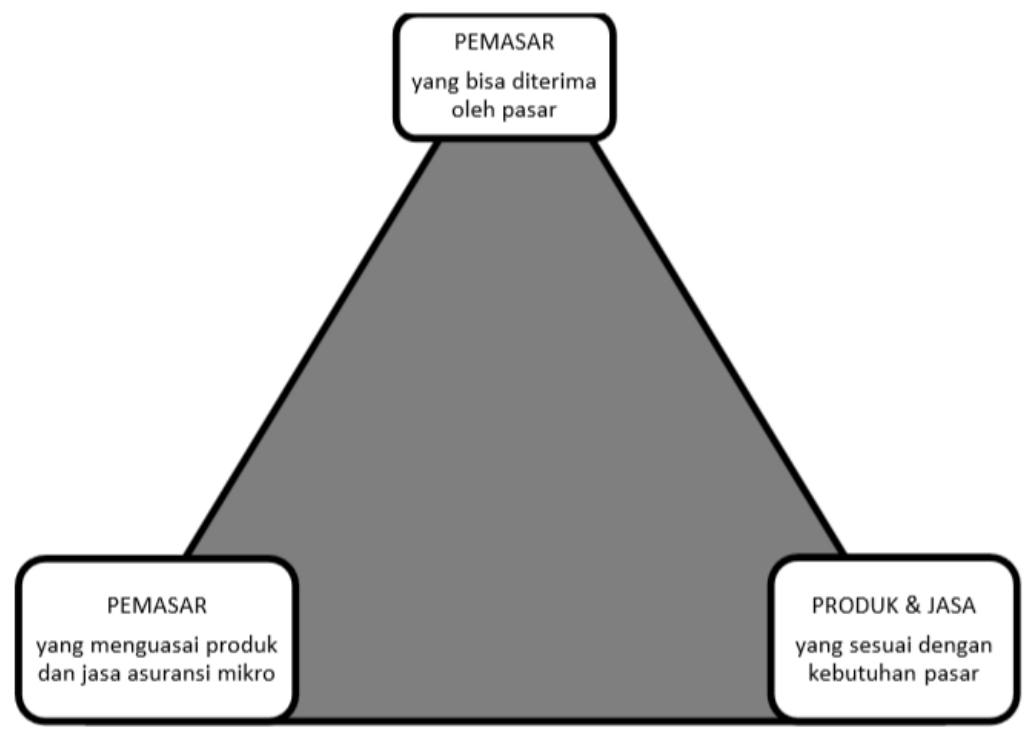

Gambar 3

Model Pemasaran Asuransi Mikro

Banyak perubahan yang akan terjadi di industri asuransi selama lima tahun ke depan. Transformasii ini mencakup penerapan teknologii informasi. Sebagaii perbandingan, situasi sekarang sangat berbeda dengan lima tahun lalu. Semua upayaa bisnis dan pemasaran, baik sekarang maupun di masa depan, harus 


\section{VISA: Journal of Visions and Ideas}

\section{Vol 1 No 3 (2021) 261-273 E-ISSN 2809-2058 P-ISSN 2809-2643 DOI: $47467 /$ visa.v1i3.795}

dirancang dengan keterampilan teknologi informasi yang sesuai. Alhasil, apapun yang dilakukan para ahli akan diakui secara luas dan akan membantu seluruh operasional perusahaan dari hulu hingga hilir. Profesionalisme dalam pengelolaan pasar, serta kemampuan mengelola produk yang dapat diterima pasar dan pendampingan TI dalam mengantarkan produk ke pasar, seharusnya memberikan nilai lebih terhadap manajemen yang baik di kantor pusat maupun di kantor operasional.

Alhasil, faktor kepemimpinan perusahaan dalam hal ini kantor pusat dapat menjadi koordinator yang baik dan mendukung kemajuan perusahaan, yaitu pemaasar dan profesional yang terlibat dan didukung oleh teknologi informasi yang tepat, dan beberapa masalah bisnis. dapat dikelola dengan benar. 


\section{VISA: Journal of Visions and Ideas}

\section{Vol 1 No 3 (2021) 261-273 E-ISSN 2809-2058 P-ISSN 2809-2643 \\ DOI: 47467/visa.v1i3.795}

\section{Pentingnya Asuransi Mikro dalam Kesejahteraan UMKM Indonesia}

Asuransi mikro memainkan peran yang pentiing dalam memperbaiki ekonomi masyarakat berpenghasilan rendah, dengan asuransi mikro di Indonesia berfungsi sebagai katup penyelamat dari kemiskinan dan keputusasaan ketika bencana alam terjadi. Asuransi mikro di Indonesia memberikan alternatif opsi pengalihan risiko bagi rumah tangga berpenghasilan rendah, seperti membayar pendidikan anak jika pencari nafkah keluarga meninggal, membayar perawatan kesehatan ketika salah satu anggotaa keluarga sakit, atau melindungi petani kecil dari gagal panen akibat perubahan iklim.

Disebabkan banyaknya manfaat yang dapat diperoleh melalui asuransi mikro, maka hal ini termasuk dalam inisiatif Keuangan Inklusif yang dicanangkan oleh Bank Indonesia dan Otorotas Jasa Keuangan. Pada bidang pertaniian, misalnya, ada asuransi mikro berupa Crop Insurance, yang memungkinkan petani meng-cover hasil panennya sehingga jika terjadi gagal panen, mereka bisa mendapatkan uang melalui asuransi. Otoritas Jasa Keuangan juga mempertimbangkan asuransi bencana mengingat Indonesia terletak di sabuk gempa Pasifik, dan ketika terjadi bencana, itu menyebabkan kerugian yang signifikan bagi masyarakat, terutama mereka yang ekonominya miskin.

Asuransi miikro bukan hanya memberiikan keuntungan bagi masyarakat berpenghasilan rendah, juga memberikan manfaat bagi perusahaan asuransi khususnya perusahaan yang telah memiliki produk asuransi mikro, karena ketika pertama kali dikenal oleh masyarakat ekonomi lemah akan menjadi pilihan asuransi bagi komunitas ini dan berpotensi untuk diwariskan dengan berbagi informasi tentang asuransi mikro dengan orang-orang di sekitar mereka, sehingga lebih banyak orang membeli asuransi mikro dan berdampak positif.

Namun, banyak perusahaan asuransi terus mengabaikan pasar asuransi mikro Indonesia karena tarifnya jauh lebih rendah dari pada premi asuransii pada umumnya dan dianggap memberikan keuntungan yang tidak signifikan. Namun berkatt promosi OJK terhadap asuransi mikro dan kerjasama berbagai pihak, perusahaan asuransi kini menawarkan produk asuransi mikro yang lebih beragam.

Sejak diperkenalkannya asuransi mikro kepada masyarakat yang kurang mampu secara ekonomi, masyarakat memiliki alternatif asuransi berdasarkan kebutuhan dan kapasitas mereka, meningkatkan kesadaran berasuransi di kalangan masyarakaat Indonesia dan berkontribusi pada tinggiinya jumlah pengguna asuransi di tanah air. Asuransii mikro memiliki dampak sosial dengan berfungsi sebagai penyelamat ekonomi bagi mereka yang berpenghasilan rendah, dan akan mendorong pertumbuhan ekonomi, ketahanaan ekonomi, dan memberikan kontribusi yang signifikan bagi industri keuangan Indonesia dalam jangka panjang.

Dapat dikatakan bahwa ekspansi asuransi mikro berdampak domino terhadap bisnis asuransi, ekonomi, dan keuangan di Indonesia. Selama ini keterbatasan asuransi mikro di Indonesia dalah belum adanya peraturan perundang-undangan bagi landasan hukum yang terkait dengan asuransi mikro 
untuk memungkinkan perluasan pelaksanaan Grand Design asuransi mikro di Indonesia..

Seperti contoh Sinta menggunakan asuransi kesehatan demam berdarah untuk seluruh anggota keluarganya dari sebuah perusahaan asuransi seharga Rp 50.000, harga ini menunjukkan nilai asuransi mikro di masyarakat. Sinta membeli asuransi kesehatan mikro setelah mengetahui bahwa banyak orang di lingkungannya menderita demam berdarah (DBD). Sinta merasa bahwa karena harga asuransinya murah, dia tidak akan mengalami kerugian finansial jika tidak menggunakannya. Anak bungsu Sinta terserang demam berdarah satu bulan setelah membeli asuransi kesehatan (DBD).Sinta juga mengajukan klaim dengan mengirimkan SMS sesuai petunjuk pada voucher asuransi. Perusahaan asuransi menelepon keesokan harinya untuk menanyakan kelengkapan dokumen dan hasil tes. Seminggu setelah Sinta menyerahkan dokumen, bisa klaim asuransi sebesar Rp. 2.000.000,00 disetorkan langsung ke rekening banknya, tanpa potongan. Berdasarkan rasio nilai premi dan manfaat yang ditawarkan, premi asuransi dapat dianggap mikro dengan manfaat makro.

\section{PENUTUP}

Berdasarkan hasil diskusi diatas, dapat diambil kesimpulan yaitu :

1. Jenis Asuransii mikro dapat dipasarkan melalui pembentukan jaringan komunitas-komunitas kecil yang mayoritas berada di kalangan menengah ke bawah.

2. Barang dan jasa asuransi mikro yang dijual oleh pemasar menggunakan teknik seperti database pasar (komunitas).

3. Untuk berinteraksi dengan kelompok-kelompok tersebut, pemasar harus terampil menjelaskan manfaat barang perusahaan; dan

4. Membangun operasi pemasaran dan bisnis berbasis TIK yang memadai

Masyarakat kalangan menengah ke bawah sangat membutuhkan asuransi yang sesuai dengan kemampuan ekonomi mereka namun selama ini belum mengerti dan memahami prosedur untuk mengaksesnya sehingga banyak diantara mereka yang belum ter-cover oleh asuransi terutama sekali asuransi dibidang kesehatan yang paling krusial saat ini. Perlu dilakukan Edukasi oleh seluruh pihak yang berkepentingan agar masyarakat sadar akan manfaat asuransi bagi masa depan mereka yang tidak pasti. Perusahaan asuransi pemilik produk asuransi mikro harus membuka lebar pintu kerjasama dengan berbagai lembaga keuangan yang ada untuk memeasarkan produk asuransinya. Akses pendaftaran asuransi secara online juga bisa dimanfaatkan untuk menjangkau masyarakat yang belum dapat dijangkau oleh lembaga-lembaga keuangan baik mikro maupun yang lainnya. 


\section{VISA: Journal of Visions and Ideas \\ Vol 1 No 3 (2021) 261-273 E-ISSN 2809-2058 P-ISSN 2809-2643 \\ DOI: 47467/visa.v1i3.795}

\section{DAFTAR PUSTAKA}

Ahmad Ghifari. (01 Desember 2021). Peminat asuransi mikro diprediksi akan terus bergairahKontan.https://keuangan.kontan.co.id/news/peminatasuransimikrodiprediks i-akan-terus-bergairah

Awaloedin, M. (2021). Analisis Bisnis Asuransi Mikro di Indoensia, Junrla Enterpreneur dan Manajemen Sains, 143-151.

Badan Pusat Statistik. (2015). Potret Awal Pembangunan Pasca MDGS, Sustainable Development Goals (SDGS), Badan Pusat Statistik, Jakarta.

Christian Biener, Martin Eling, dan Joan T. Schmit. (2014). Regulation in Microinsurance Markets: Principles, Practice, and Directions for Future Development, World Development Vol. 58, pp. 21-40.

Daniel J. Clarke, dan Dermot Grenhamb. (2013). Microinsurance and natural disasters:Challenges and options, Environmental Science \& Policy 27s (2013) 89 - 98.

Hendri Saparini. (2015). Peran Ilmu Pengetahuan Dalam Menjawab Tantangan Dan Menawarkan Terobosan Untuk Mewujudkan Kesejahteraan Sosial: Dari MDGS Menuju SDGs diampaikan dalam KIPNAS XI, 2015 di LIPI, Jakarta.

Julie Robson. (2015). "General insurance marketing: A review and future research agenda", Journal of Financial Services Marketing Vol. 20, 4, 282-291.

Otoritas Jasa Keuangan. (2015). Peraturan Otoritas Jasa Keuangan Nomor 23 /POJK.05/2015 "Tentang Produk Asuransi Dan Pemasaran Produk Asuransi".

Peter W. Roberts. (2013). The Profit Orientation of Microfinance Institutions and E ff ective Interest Rates, World Development Vol. 41, pp. 120-131.

Rimawati, Kurnia, T., \& Alhifni, A. (2019, July-Desember Bogor). Analysis Of Micro Insurance Models For Fishermans (Studi in Sukabumi and Pangandaran Port). JEBIS, 5 (2), 134-167.

Tim Pengembangan Asuransi Mikro. (2013). Grand Design Pengembangan Asuransi Mikro Indonesia, Otoritas Jasa Keuangan (OJK), Jakarta.

Trevor Watkins, (1988),"The Use Of Information Technology In Insurance Marketing", Marketing Intelligence \& Planning, Vol. 6 Iss 2 pp. 21 - 26.

https://keuangan.kontan.co.id/news/ini-cara-perusahaan-dongkrak-bisnis-asuransi-mikro (01 Desember 2021).

https://datapolis.id/database/seojk-nomor-9-seojk-05-2017-produk-asuransi-mikro-dansaluran-pemasaran-produk-asuransi-mikro/ (01 Desember 2021) 